\title{
WILL NOT MORALITY NECESSARILY IMPROVE?
}

\author{
The Correlation Between Morality and Net Fertility Found in Royal Families \\ May Be True in All Classes of Society-Decline in the Birth \\ Rate Brings in New and Favorable Factors
}

Frederick AdAMS WoOdS

Lecturer on Biology, Massachusetts Institute of Technology

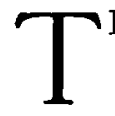

$\mathrm{HE}$ writer of the article in the October number of the Journal of Heredity, "Will Morality Disappear?" Mr. Paul Popenoe, quotes my conclusion drawn from "Heredity in Royalty," which is that, on the average, those who were superior morally had the largest families of children reaching 21 years or more, while the morally inferior were less fertile. He also states, "While this single investigation is not adequate proof of the correlation between morality and net fertility, yet the result is no more than one would expect. There are many reasons, both medical and economic, why the children of the more vicious and depraved naturally die in greater numbers; and if they do, then the evolution of a higher moral state has been brought about partly by selective breeding."

The writer continues, "Royal families furnished particularly good material to test the problem, because there has probably been no artificial restraint of the birth rate there; reasons of policy make monarchs desire to have as large families as possible."

I agree that royal families furnished particularly good material to test the problem, but not "because there has probably been no artificial restraint of the birth rate there." The material is good because here enough is known about the individuals to compare the numbers of the offspring of own brothers and own sisters. Even if the total became restricted in modern times, it would merely lead to a smaller total for all living royalty; it would not per se affect the quality.

It is the inability to compare and contrast the numbers of brothers' offspring with brothers' offspring and sisters' with sisters' that makes most of the seemingly pessimistic evidence much less significant to the problem of the evolution of morality than is commonly supposed.

For instance, Popenoe quotes Galton, who made a study of famous divines and found them to be a "moderately prolific race, rather under than above the average." But are they not, I ask, as prolific as the average of their own social class, or, better still, are they not more prolific than the worst of their own close blood relations?

It is probable that within each social group internal forces of selection and survival are working towards improvement of the quality of the group. The total quantity of the best groups may be diminishing. There can be no question but that the birth rate among America's biologically best has of late rapidly declined. If it should keep on declining, the end of course is obvious. But many unsuspected correctors arise in nature when new factors are introduced into the struggle for existence.

\section{NEW FORCES AT WORK}

Hitherto, until within a very few years, voluntary restriction of parenthood was comparatively seldom practiced. Now that it is practiced to a far greater extent than formerly, a 
new differentiation must begin, based on the parental instinct. That is, to put it in a simple way, those who are more desirous of children will have more children, and the parental instinct itself will become an element of selective value. It is the fashion for reformers to blame the selfish for not having chlildren. That may be good preaching, but it does not get around the fact that, as far as heredity is concerned, we have now a new force working towards improved racial morality and towards the elimination of selfishness.

Here there is undoubtedly at least one vigorous corrector which must from now on begin to take effect. How far it will go we cannot say. It is a force which, within my observation, has not been sufficiently recognized in discussions on the declining birth rate. It is a force springing from one of the most fundamental of instincts, and should soon make itself felt in increasing measure.

The parental instinct is doubtless bound up with many excellent moral traits, such as domesticity, stability and sympathy. There is reason, then, to foresee a better morality in the future, based willy villy on natural selection.
Another matter should be kept in mind and that is the fact that the whole nation is not, from a genealogical or natural-history point of view, in any true sense, a melting pot. Classes, subraces, breeds, and even professions tend to herd with themselves. Most marriages occur within the same social class. For this reason we must study intensively each group separately, tracing its rise and decline in quality and quantity. We must not think that we can get an idea of the merit of the United States by adding up all the qualities of its citizens and dividing by one hundred and ten million; nor should we despair. if a $5 \%$ upper crust of educated classes shrank to a $3 \%$ through a greater swelling of the unleavened masses. If the upper classes can hold their actual numbers and improve by internal forces, this will be a great deal to be thankful for. The above is written merely to point out that the future is not necessarily so dark as some people suppose; it is not a suggestion that active eugenic propaganda is not needed or that governmental and legislative control may not greatly aid in the improvement of the American people.

\section{Wanted, Photographs of Twins}

The American Genetic Association desires to communicate with twins living in any part of the world. It has been discovered that twins are in a peculiar position to help in the elucidation of certain problems of heredity. Good photographs at all ages are especially desired in order to determine the degree of resemblance and its persistence through life. Any information, giving the addresses of twins, who are willing to cooperate with the Association will be keenly appreciated.

It is known that there are two sorts of twins. (1) The true or "IDENTICAL" twins are developed from a single original egg cell which at some very early stage divided to form two individual beings. These "identical" or "duplicate" twins have a nearly (though never an absolutely) identical germ plasm, are always of the same sex and resemble each other to an extraordinary degree. (2) The other kind, "FRATERNAL" twins are no more alike than brothers and sisters born at different times. They are developed from two separate egg: cells.

It is fortunate for our knowledge of heredity that there are these two kinds of twins, on account of the chance it gives to study the relative importance of the influence of heredity and of environment.

It is for the study of this fundamental question of the degree of influence exerted by environment as compared with that due to heredity that the cooperation of the twins of the world is solicited and any publicity given to this notice by the press will be of great assistance.

All communications should be directed to the American Genetic Association, Washington, D. C. 